\title{
CHINESE PARTICIPATION IN THE DEVELOPMENT OF BRITISH CONCESSION IN TIANJIN, CHINA
}

\author{
中国天津における英租界の開発への中国人の関わり \\ Yichen LIU ${ }^{* 1}$ and Masaki FUJIKAWA*2 \\ 劉一辰, 藤川昌 樹
}

The Concession, up till now, have been recognized as a country in another. This study focuses on the British Concession in Tianjin, elucidate (1)The involvement Chinese people had in the operational management in the British Concession (2)The property development by Chinese people in the concession (3)The styles of the architectures in the Concession in Tianjin.

The conclusion shows the concession area was not simply a country in another, the administration and the further development were largely done by Chinese, it was gradually utilized by Chinese people.

\section{Keywords : Colonial, City planning, Settlement, Assimilation, Mimicked Western-style architectures 植民地，都市計画，居留地，同化，擬洋風建築}

\section{Introduction}

In modern history, concessions ruled by foreign countries can be found in Asia and many other places in the world, such as Tianjin, Shanghai and Guangzhou in China which were all developed based on the constructions in concessions. The constructions in those cities were originated from the Concessions and further developed to what the streets are like now. These cities are said to be like "Implanted cities", "countries within a country" ${ }^{* 11}$. That was referring to them which existed lonely and so differently from others. However, was it really so?

In this study, the British Concession was used as an example. In Tianjin (Tientsin), Concessions were developed by nine nations from the middle of the $19^{\text {th }}$ century onwards. At any given point, there were a maximum of eight nations simultaneously existed. The British Concession was first established after the Arrow war in $1860^{* 2)}$, and extended three times thereafter. Following these extensions, it became the largest concession in Tientsin, existing for approximately 80 years ${ }^{* 3)}$. In the 2000's, the area was assigned as a historical location, comprising of various culturally significant buildings.

The purpose of this research is to explain the management of the expansion in concession and of the transportation, the level of involvement of Chinese people at different stages. It includes that the Councilors of the British Municipal Council included Chinese and they became the main power. It also demonstrated that the change of the constructional styles. Based on the analysis of the Concession to seek the value of them to discover the important influence concessions had on the formation of the city and the culture.

Regarding " Implanted cities ", Colonial cities were defined as "implanted cities " in Robert Home's book, "Of Planting and Planning: The making of British colonial cities" (1997) *4). This issue discussed the evolution and the refinement of the colonial city construction including the settlement set up by Britain from the 1600s, and the impact on later urban planning philosophy. Meanwhile, after the Opium war, Great power established concessions in China. And until now, the concessions have been recognized as " countries within a country " in domestic researches of China. For example, Wang (1984) *5) defined Zhenjiang's British Concession as " countries within a country " and outlined the historical background from the opening to being returned. Most of these researches recognize the history of ' countries within a country ' like concessions as a humiliation from the viewpoint of nationalism, and call on reflection on being colonized.

In addition, many previous studies on foreign settlements and concessions can be confirmed. ONDA (2003) *6) cleared the formation process of the urban space consisted the wharf, the street, the urban subdivision, and architecture. The target is harbor space of Amoy,

*1 Assist. Prof., Dept. of Architecture and Civil Eng., Toyohashi Univ. of Tech., Dr.Env.

*2 Prof., Faculty of E.I.S., Univ. of Tsukuba, Dr.Eng.
豊橋技術科学大学 助教・博士 (環境学)

筑波大学システム情報系＼cjkstart教授・博士(工学) 


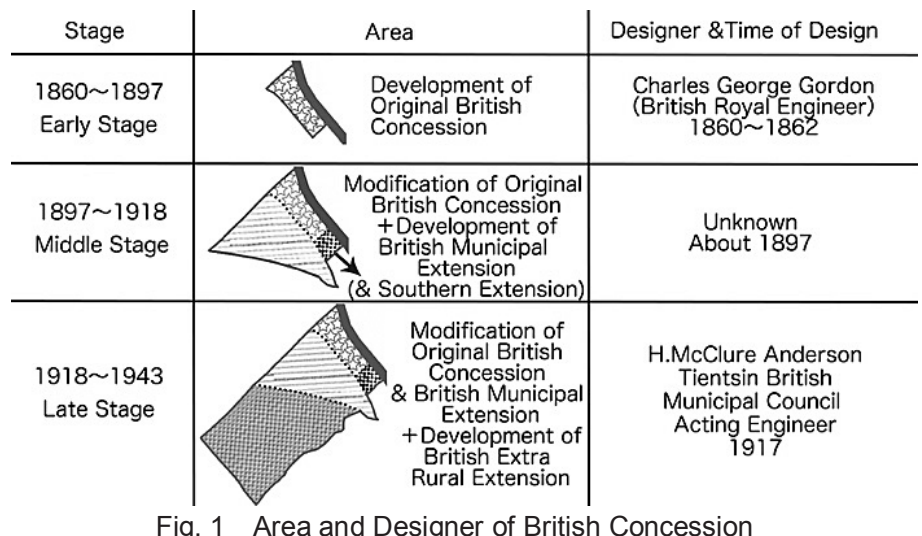

which was a historical trading city at Fu-jian in China. Considering complete of the customhouse and wharves after Dutch factory was founded, it became clear that Amoy was formed as trading city of China in premodern times. And, exploring the influence which built-up area had on British settlement after Opium War and the remaking Amoy from 1920's to 30's, it reveal the formation of harbor's space is continuous from premodern times.

About Tianjin, Wang $(1995){ }^{* 7)}$ compiled the change of the use of buildings and land, and analyzed the characteristics of each concession until 1943. Liu (2014) $(2015) *$ *8, *9) and Chen $(2017){ }^{* 10)}$ conducted a detailed study of city planning concept and development about the British concession. Especially for the Original British concession, and the third expansion, the British Extra Rural Extension, explain the planner's, planning intentions, and construction process.

This research is focused on the management, the structure of the development and the constructions, and the impact they had on the society. The research also demonstrated how Chinese moved to these areas to live, then got involved in the politics and the management, within these "Implanted Aliens" Chinese learned some advanced technology and some new mentality of management, Chinese culture was expanded and found its roots there.

2. Methods

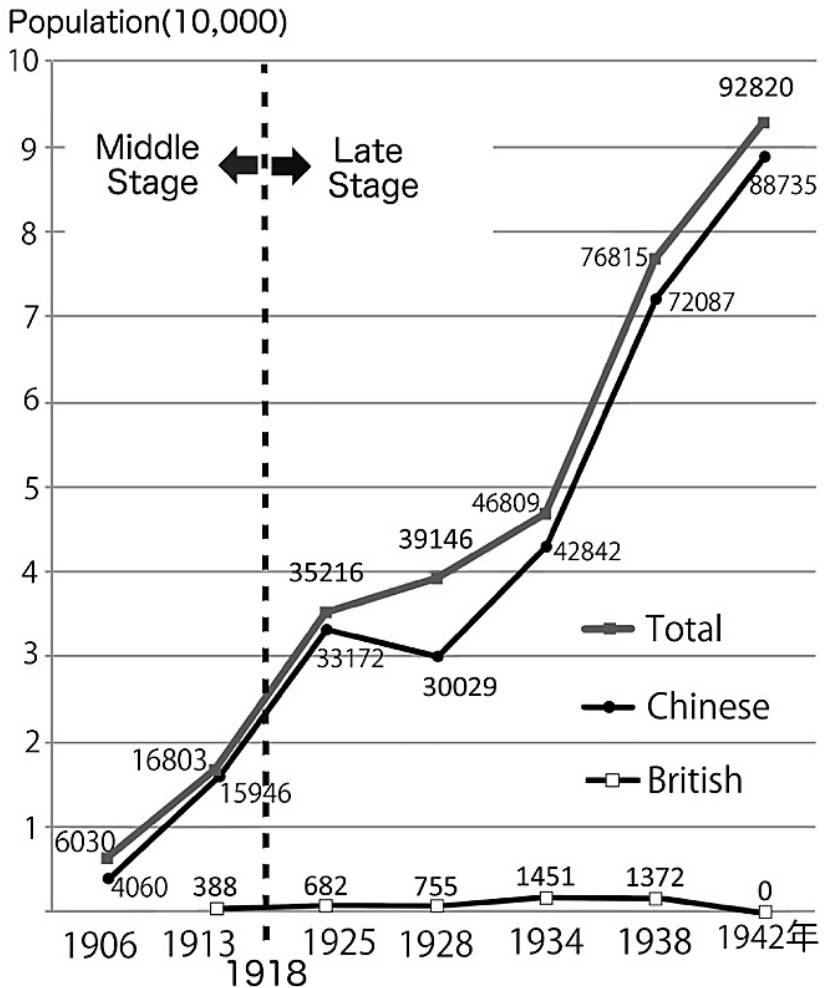

Fig. 2 Population of British Concession

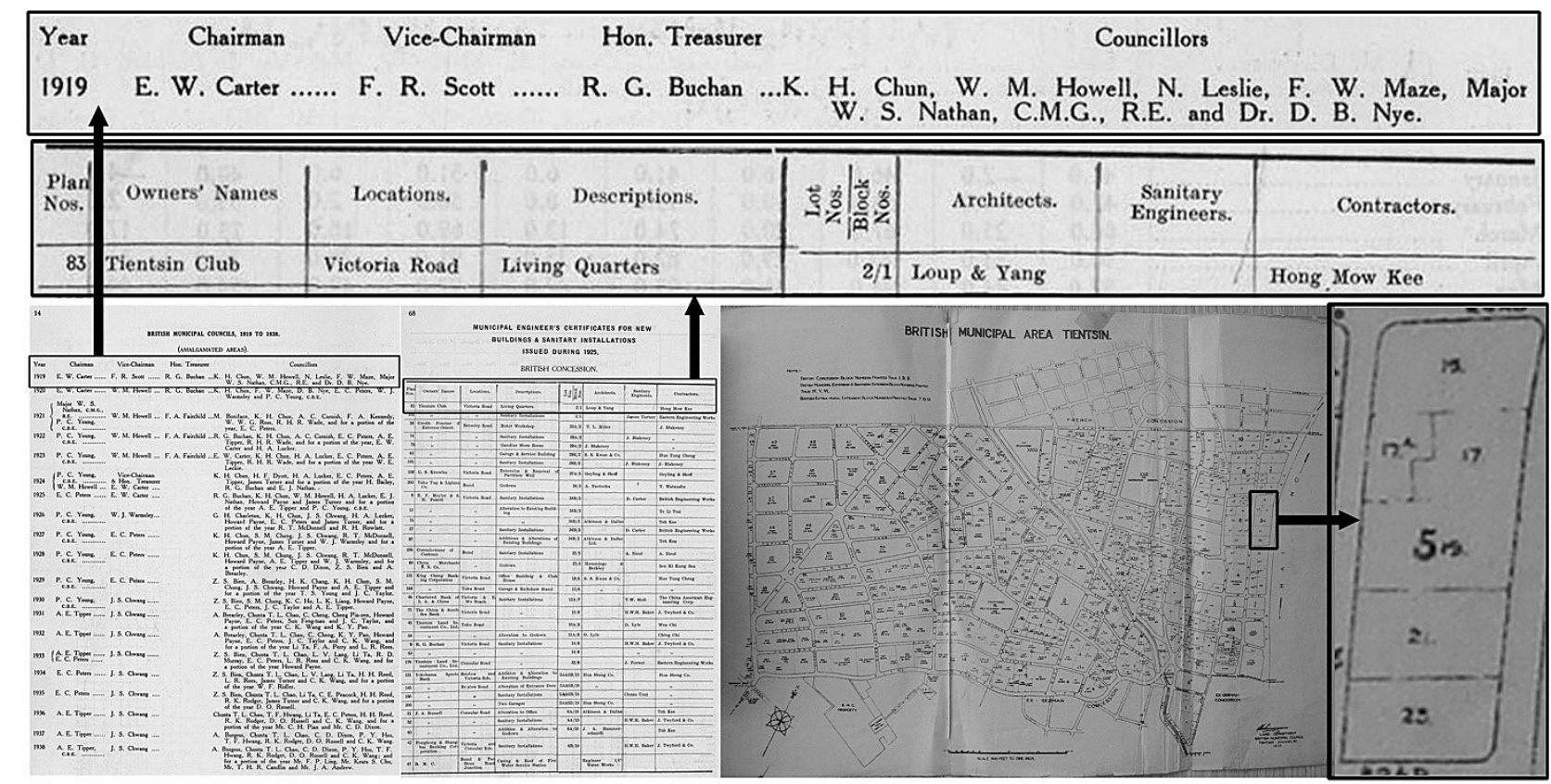

Fig. 3 Historical Materials, British Municipals Councils (Left), Municipal Engineer's Certificates for New Buildings \& Sanitary Installations Issued During 1925. (Center), British Municipal Area Tientsin (Right) 
The British concession expanded three times, the time and the designers of these three expansions were different. This research followed the time line of the expansions and divided it into three stages, Early stage, Middle stage and Later stage. (Fig.1). The early stage was from 1860 to 1897. The Later expansion was from 1918 to 1943 when the Nationalist party took over the British concessions. This research focused on the increase number of Chinese residents in the concessions so as to demonstrate the development and management of the concessions were gradually taken by Chinese people (Fig.2). During the Mid-stage, the increase number of Chinese population was obvious, in 1942, just before the Concession was given back to China, 90 percent of the residence were Chinese.

In this paper, as an important historical material, the newly discovered "REPORTS OF THE BRITISH MUNICIPAL COUNCILS, AND MINUTES OF THE ANNUAL GENERAL MEETINGS" (Tianjin Archivation Collection) has been used. In this historical material, the composition of the staff of British Municipals Councils were recorded, and it is possible to distinguish either Chinese or foreign from the spelling of names. Furthermore, detailed information on construction of the facilities were recorded in this historical material. In particular, the name of the owner who built the facility is recorded, and it also can be grasped the actual situation of the construction activities by the Chinese. In the annual report for 1916, 1917, 1918, 1919, 1920, 1921, 1922 and 1925, the specific position where the construction work was carried out is stated and it was written in 1925 . I was able to confirm on the map which was found in the published book "Tientsin: An Illustrated Outlined History" by O.D.Rasmussen (Fig.3).
Table1 The member of Council's Councilors during the early stage (from REPORTS OF THE BRITISH MUNICIPAL COUNCILS, AND MINUTES OF THE ANNUAL GENERAL MEETINGS 1938)

\begin{tabular}{|c|c|c|c|}
\hline Year & Chairman & Hon.Treasurer & Councillors \\
\hline 1862 & E.Waller & J.Henderson & J.Hanna \\
\hline 1863 & E.Waller & W.M.Norton & J.Hanna \\
\hline 1864 & E.Waller & J.Livingstone & J.Hanna \\
\hline 1865 & J.Hanna & D. Eastwood & J.A.T.Meadows \\
\hline 1866 & J.A.T.Maeadows & \multicolumn{2}{|c|}{$\begin{array}{l}\text { I.H.McClure, H.C.Maclean S.J.Morris } \\
\text { J.Livingstone }\end{array}$} \\
\hline 1867 & J.A.T.Maeadows & J.Livingstone & J.Hanna, H.G.Howard \\
\hline 1868 & J.A.T.Maeadows & J.Henderson & G.Hugbes, J.Livingstone \\
\hline 1869 & J.A.T.Maeadows & J.Hanna & J.Livingstone \\
\hline 1870 & $\begin{array}{l}\text { J.A.T.Maeadows } \\
\text { J.Henderson }\end{array}$ & H.G.Howard & J.Hanna \\
\hline 1871 & J.A.T.Maeadows & M.G.Moore & A.C.Cordes \\
\hline 1872 & J.A.T.Maeadows & M.G.Moore & H.Beveredge, A.C.Cordes \\
\hline 1873 & E.A.Solomon & $\begin{array}{l}\text { J.Livingstone } \\
\text { J.A.T.Meadows }\end{array}$ & H.Beveredge, J.J.Hatch, M.G.Moore \\
\hline 1874 & E.A.Solomon & J.J.Hatch & W.Forbes, J.A.T.Meadows, M.G.Moore \\
\hline 1875 & $\begin{array}{l}\text { J.A.T.Meadows } \\
\text { M.G.Moore }\end{array}$ & $\begin{array}{l}\text { J.J.Hatch } \\
\text { S.A.Natch }\end{array}$ & A.C.Cordes, W.Forbes, W.Jackson \\
\hline 1876 & N.G.Moore & A.C.Cordes & $\begin{array}{l}\text { H.Beveredge, W.Gubbins, J.Henderson, } \\
\text { W.Jackson, A.Macpberson }\end{array}$ \\
\hline 1877 & J.Henderson & P.L.Laen & W.Gubbins, J.J.Hatch, A.D.Startseff \\
\hline 1878 & G.Detring & W.Gubbins & J.Henderson, P.L.Laen, Liao Too Sang \\
\hline 1879 & G.Detring & D.Ezekiel & $\begin{array}{l}\text { W.Gubbins, W.Forbes, A.K.Kooznetseff, } \\
\text { A.D.Startseff }\end{array}$ \\
\hline 1880 & G.Detring & $\begin{array}{l}\text { D.Ezekiel } \\
\text { SA.Hardoon }\end{array}$ & W.Forbes, W.Gubbins, A.D.Startseff \\
\hline 1881 & G.Detring & S.A.Hardoon & W.Forbes, W.Gubbins, A.D.Startseff \\
\hline 1882 & W.Gubbins & S.A.Hardoon & E. Farago, W.Forbes, H.E.Hobson \\
\hline 1883 & H.E.Hobson & F.de Bovis & E.Cousins, W.Forbes, A.D.Startseff \\
\hline 1884 & H.E.Hobson & $\begin{array}{l}\text { F.de Bovis } \\
\text { G.C.de St }\end{array}$ & $\begin{array}{l}\text { E.Cousins, W.Forbes, J.Grabam } \\
\text { A.K.Kooznetseff, A.D.Startseff }\end{array}$ \\
\hline 1885 & G.Detring & W.W.Dickinson & E.Cousins, W.Forbes, A.D.Startseff \\
\hline 1886 & G.Detring & W.W.Dickinson & E.Cousins, W.Forbes, A.D.Startseff \\
\hline 1887 & G.Detring & $\begin{array}{l}\text { W.W.Dickinson } \\
\text { A.D.Startseff }\end{array}$ & $\begin{array}{l}\text { E.Cousins, W.H.Forbes, Dr.A.Irwin } \\
\text { A.D.Startseff }\end{array}$ \\
\hline $\begin{array}{l}1888 \\
1889\end{array}$ & $\begin{array}{l}\text { G.Detring } \\
\text { G.Detring }\end{array}$ & $\begin{array}{l}\text { A.D.Startseff } \\
\text { A.D.Startseff }\end{array}$ & $\begin{array}{ll}\text { E.Cousins, W.H.Forbes, } & \text { R.Lnglis, Dr.A.Irwin } \\
\text { E.Cousins, W.H.Forbes, R.Lnglis, Dr.A.Irwin }\end{array}$ \\
\hline 1890 & G.Detring & W.W.Dickinson & E.Cousins, W.H..Forbes, A.D.Startseff \\
\hline 1891 & G.Detring & W.W.Dickinson & E.Cousins, W.H.Forbes, A.D.Startseff \\
\hline 1892 & G.Detring & W.W.Dickinson & E.Cousins, A.D.Startseff, J.Wilson \\
\hline 1893 & G.Detring & W.W.Dickinson & $\begin{array}{l}\text { R.A.Cousens, E.Cousins, J.Stewart, } \\
\text { A.D.Startseff, J.Wilson }\end{array}$ \\
\hline 1894 & W.W.Dickinson & $\begin{array}{l}\text { R.A.Cousens } \\
\text { J.Wilson }\end{array}$ & Dr.A.Lrwin, W.Fisder, J.Stewart \\
\hline 1895 & $\begin{array}{l}\text { W.W.Dickinson } \\
\text { E.Cousins }\end{array}$ & $\begin{array}{l}\text { R.A.Cousens } \\
\text { J.Wilson }\end{array}$ & W.Fisder, D.H.Mackintosh, J.Stewart \\
\hline 1896 & E.Cousins & J.M.Dickinaon & $\begin{array}{l}\text { W.C.C.Anderson, E.Cousins, J.Stewart, } \\
\text { Ross Thomson }\end{array}$ \\
\hline 1897 & $\begin{array}{l}\text { E.Cousins } \\
\text { J.M.Dickinson }\end{array}$ & $\begin{array}{l}\text { J.M.Dickinaon } \\
\text { W.C.C.Anderson }\end{array}$ & W.Fisder, M.March, J.Stewart \\
\hline
\end{tabular}

\section{The early stage of Tianjin's British Concession}

3. 1. The management system during early stage of British Concession

Represented by the British concession, all the concessions were under the direct leadership of the consulates at the early stages of concession era. As the increase number of locals moved to live in these areas, the system of management in Concessions became the same as they had in their own countries. Being an autonomous region the British Concession residents were given the power to self-govern the area. The management systems and the level of management by the residents varied in different concessions in Tianjin, from the almost total self-governed British Concessions to the monopoly of the French Consulate over the management of their concessions, all the rest of the concessions are somewhere in between them. Excluding Japanese Concessions, everyone else had formed a Municipal Council.

The city management systems are the same in Tianjin and in Shanghai, the British concession formed the Municipal Council in 1862 , it became an organization to make final decisions/policies. The Municipal Council Councillors were formed by tax payers in the concession, the term is one year, when a term finished a new vote will happen. This form is similar to the current local autonomy management model. According to the Regulations of the British Municipal Council, the election of the British Concession will be known as the "ELECTION OF AUDITORS", held "Annual General Meeting" and "Special Meeting", two meetings by the British Consulate, the consulate has the right to the resolution. The final verdict of the matter and verbal negation, and may exercise the veto in writing within 7 days. However, in fact, the British consul on the concession of the daily administration is basically not interfere with*11), so the highest degree of autonomy. The Regulations of the British Municipal Council was clearly stipulated in the organization and authority of the Council. At least 20 years old, qualification for one Owner's Vote must be Tls. 200 and that for one Occupier's Vote must be Tls. 600. In six months prior to the registration of the right to vote, the immovable property with a value of Tls. 600 in the concession will be eligible for election. The number 


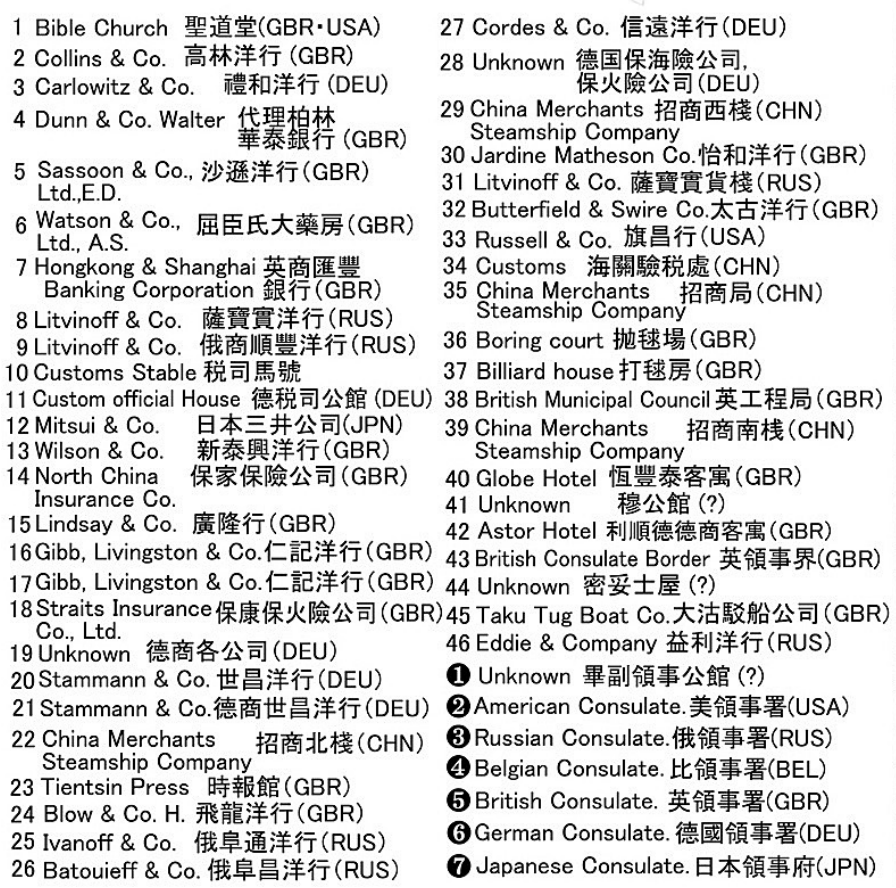

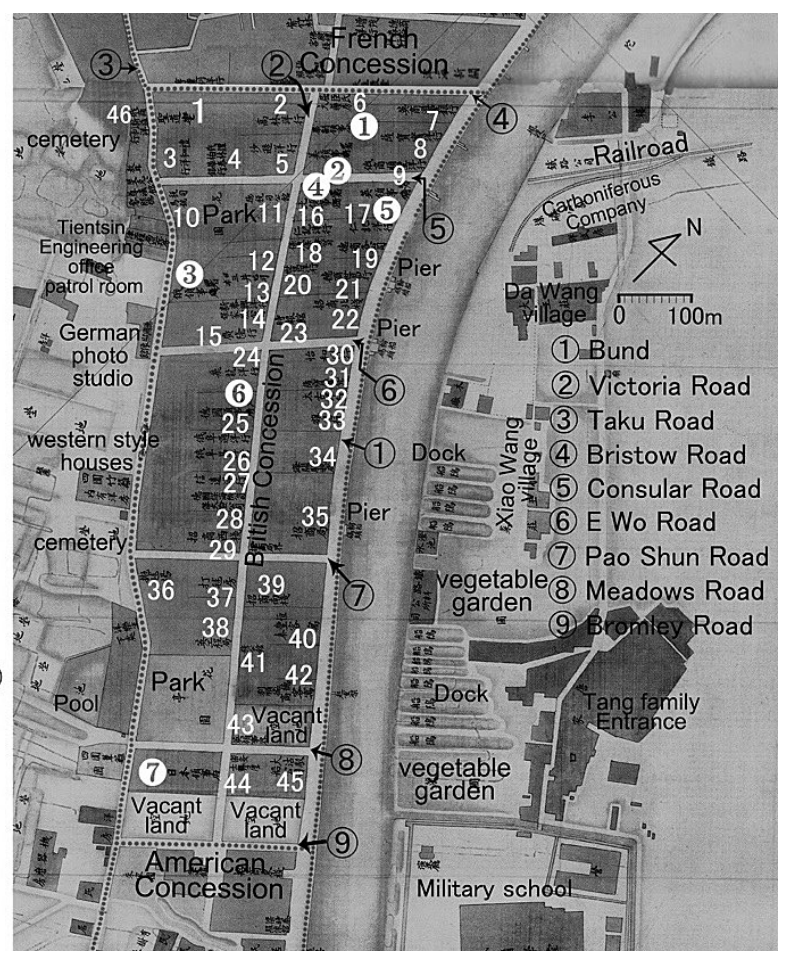

Fig.4 British Concession (1888)

of recommended candidates should not exceed 10 people, if more than 10 people, then 10 people must be selected at "Annual General Meeting". If 10 people (including 10) more than 5 people, directly composed the Council. If the recommended candidates were less than 5 people within 10 days prior to the date of the meeting, the consular would decide directly for the candidate*12). In fact, up to 1897 , the member of Council's Councilors were between 3 to 7 (Table1). Among the Municipal Council in 1887 there was only one Chinese, the rest were all foreigners. From 1862 to 1864 the chairman of the Municipal Council was E. Waller from the Phillips and Moore. From 1866 to 1872, the chairman was J.A.T Meadows It can be seen that the Council's Councilors were formed by foreign businessmen who were operating mercantile house. Between 1878 and 1893, for 13 years except 1882,1883,1884, the Chairman of the Council was held by Gustav Von Detring, who had a close relationship with Li Hongzhang(李鴻章) *13). The only Chinese Councillor was Liao Too Sang, who was a managing clerk of China Merchants' Steam Navigation Company（輪船招商津局）*14). China Merchants' Steam Navigation Company, organized by Li Hongzhang, was the product of the Westernization movement.

\section{2. The development during early stage of British Concession}

The planning of the original British Concession was done by Charles George Gordon, the British Royal engineer. Fig. 4 shows that in 1888 Collins \& Co. and Jardine Matheson moved in these areas, leading by Collins and Co. many other business moved in and they built many facilities. Besides that other banks and consulates were built there to make sure that Chinese business were kept at minimum number. Apart from the Chinese business which were set up during Self-Strengthening Movement, in these areas were all invested by foreign investors, very few were Chinese.

\section{3. The architectural style during early stage} of British Concession

The facades of the buildings before the Concession were all European style including all European styles, e.g. Swire built in Tianjin in1867, the building showing in photo $1^{* 15}$. It was built with pure black brick, using Green windows and red tiles to represent its style, especially the arch doors and windows, it showed obviously in Romanesque style. On the other hand, the Tientsin print house built in 1894 showing in

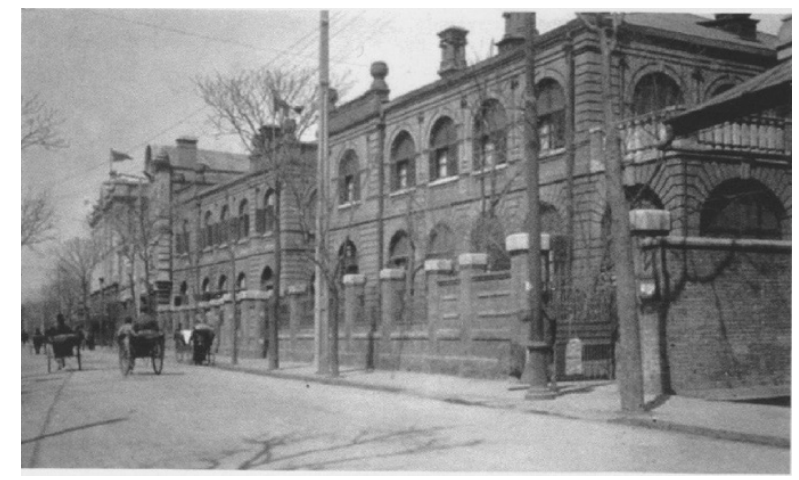

Photo 1 Swire (build in 1895)

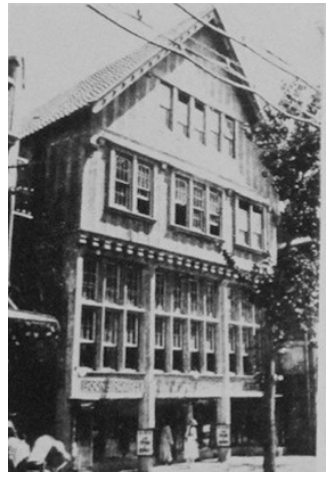

Photo 2 Tientsin Print (build in 1886) 
Table2 The member of Council's Councilors during the middle stage (Upside :

Original British Concession, Down side : British Municipal Extension) (from REPORTS OF THE BRITISH MUNICIPAL COUNCILS, AND MINUTES OF THE ANNUAL GENERAL MEETINGS 1938)

\begin{tabular}{|c|c|c|c|}
\hline Year & Chairman & Hon.Treasurer & Councillors \\
\hline 1898 & $\begin{array}{l}\text { W.W.Dickinson } \\
\text { J.M.Dickinson }\end{array}$ & W.C.C.Anderson & W.Fisder, E.Heyl, C.H.Ross, J.Stewart \\
\hline 1899 & J.M.Dickinson & E.B.Lee & Ross Thomson. \\
\hline 1900 & $\begin{array}{l}\text { J.M.Dickinson } \\
\text { E.Cousins }\end{array}$ & $\begin{array}{l}\text { E.B.Lee } \\
\text { W.W.Dickinson }\end{array}$ & W.C.C.Anderson E.Heyl J.Stewart \\
\hline 1901 & E.Cousins $\mid$ E.H & leyl, W.E.Southcott & W.W.Dickinson, W.Fisher, J.Stewart \\
\hline 1902 & W.Fisher & E.F.Makey & W.W.Dickinson, E.Heyl, D.H.Mackintosh, W.E.Southcott \\
\hline 1903 & $\begin{array}{l}\text { W.Fisher } \\
\text { J.M.Dickinson }\end{array}$ & $\begin{array}{l}\text { E.F.Makey } \\
\text { W.A.Morling }\end{array}$ & A.Cumming, E.Heyl, W.E.Southcott \\
\hline 1904 & J.M.Dickinson & W.A.Morling & J.Boyce-Kup, G.T.Edkins, E.Heyl, W.E.Southcott \\
\hline 1905 & J.M.Dickinson & W.A.Morling & J.Boyce-Kup, G.T.Edkins, W.E.Southcott, \\
\hline 1906 & J.M.Dickinson & $\begin{array}{l}\text { G.T.Edkins } \\
\text { W.M.Howell }\end{array}$ & J.Boyce-Kup, E.Heyl, C.R.Morling \\
\hline 1907 & $\begin{array}{l}\text { J.M.Dickinson } \\
\text { W.E.Southcott }\end{array}$ & W.M.Howell & $\begin{array}{l}\text { J.Boyce-Kup, G.T.Edkins, C.R.Morling, W.E.Southcott, } \\
\text { W.A.Morling }\end{array}$ \\
\hline 1908 & W.A.Morling & W.E.Southcott & G.T.Edkins, C.R.Morling, G.W.Sheppard, Ross Thomson \\
\hline 1909 & W.A.Morling & W.E.Southcott & C.R.Morling, G.W.Sheppard, Ross Thomson \\
\hline 1910 & W.A.Morling & W.E.Southcott & D.MecHaffre, C.R.Morling, G.W.Sheppard, Ross Thomson \\
\hline 1911 & W.A.Morling & W.E.Southcott & E.W.Carter, G.W.Sheppard, C.L.Maxwell, Ross Thomson \\
\hline 1912 & C.R.Morling & W.E.Southcott & E.W.Carter, C.C.F.Cunningham, Ross Thomson, C.L.Marwell \\
\hline 1913 & C.R.Morling & W.E.Southcott & $\begin{array}{l}\text { E.W.Carter, C.C.F.Cunningham, T.H.R.Shaw } \\
\text { for a portion of the year F.A.Kannedy }\end{array}$ \\
\hline 1914 & C.R.Morling & W.E.Southcott & $\begin{array}{l}\text { E.W.Carter, R.Ross Thonson, G.W.Sheppard } \\
\text { for a portion of the year C.C.F.Cunningham, T.H.R.Shaw }\end{array}$ \\
\hline 1915 & $\begin{array}{l}\text { G.W.Sheppard } \\
\text { C.R.Morling }\end{array}$ & W.E.Southcott & $\begin{array}{l}\text { R.K.Douglas, R.Ross Thonson } \\
\text { for a portion of the year E.W.Carter }\end{array}$ \\
\hline 1916 & G.W.Sheppard & E.W.Carter & $\begin{array}{l}\text { R.K.Douglas, C.R.Morling, R.Ross Thonson } \\
\text { for a portion of the year R.G.Buchan }\end{array}$ \\
\hline 1917 & $\begin{array}{l}\text { G.W.Sheppard } \\
\text { E.W.Carter }\end{array}$ & $\begin{array}{l}\text { E.W.Carter } \\
\text { R.G.Buchan }\end{array}$ & $\begin{array}{l}\text { R.K. Douglas, C.R.Morling, R.Ross Thonson } \\
\text { for a portion of the year R.G.Buchan, G.S.Knowles, W.W.G.Ross }\end{array}$ \\
\hline 1918 & E.W.Carter & R.G.Buchan & $\begin{array}{l}\text { C.R.Morling, W.W.G.Ross } \\
\text { for a portion of the year G.S.Knowles and F.W.Maze }\end{array}$ \\
\hline 1899 & J.M.Dickinson & E.B.L & $\begin{array}{l}\text { W.C.C.Anderson, E.Cousins, H.Schroeter, W.McLeish, J.Stewart } \\
\text { C.D.Tenney, Ross Thomson, Tsai Shou Chi }\end{array}$ \\
\hline 1900 & $\begin{array}{l}\text { J.M.Dickinson } \\
\text { E.Cousins }\end{array}$ & $\begin{array}{l}\text { E.B.Lee } \\
\text { W.W.Dickinson }\end{array}$ & $\begin{array}{l}\text { W.C.C.Anderson, J.Droste, E.Heyl, W.McLeish, } \\
\text { J.Stewart, C.D.Tenney, Tsai Shou Chi }\end{array}$ \\
\hline 1901 & E.Cousins & $\begin{array}{l}\text { E.Heyl } \\
\text { W.W.Dickinson }\end{array}$ & $\begin{array}{l}\text { C.Denby, W.W.Dickinson, J.Droste, W.Fisher, W.McLeish } \\
\text { C.Poulsen, J.Stewart, C.D.Tenney }\end{array}$ \\
\hline 1902 & W.Fisher & E.F.Makey & $\begin{array}{l}\text { W.W.Dickinson, J.Droste, E.Heyl, D.H.Mackintosh, W.McLeish } \\
\text { C.Poulsen, W.E.Southcott, C.D.Tenney }\end{array}$ \\
\hline 1903 & $\begin{array}{l}\text { W.Fisher } \\
\text { J.M.Dickinson }\end{array}$ & $\begin{array}{l}\text { E.F.Makey } \\
\text { W.A.Morling }\end{array}$ & $\begin{array}{l}\text { G.Baur, A.Cumming, C.Denby, E.Heyl, A.Hide, W.A.Morling } \\
\text { J.H.Osborne, W.E.Southcott, C.D.Tenney }\end{array}$ \\
\hline 1904 & J.M.Dickinson & W.A.Morling & $\begin{array}{l}\text { J.Boyce-Kup, C.Denby, G.T.Edkins, E.Heyl, J.H.Osbome } \\
\text { F.Sommer, W.E.Southcott, C.D.Tenney }\end{array}$ \\
\hline 1905 & J.M.Dickinson & W.A.Morling & $\begin{array}{l}\text { J.Boyce-Kup, C.Denby, G.T.Edkins, A.Hide, W.M.howell } \\
\text { F.Sommet, W.E.Southcott, C.D.Tenney }\end{array}$ \\
\hline 1906 & J.M.Dickinson & $\begin{array}{l}\text { G.T.Edkins } \\
\text { W.M.Howell }\end{array}$ & $\begin{array}{l}\text { E.G.Adams, J.Boyce-Kup, E.Heyl, W.M.howell } \\
\text { C.R.Morling, F.Sommer }\end{array}$ \\
\hline 1907 & $\begin{array}{l}\text { J.M.Dickinson } \\
\text { W.E.Southcott }\end{array}$ & W.M.Howell & $\begin{array}{l}\text { E.G.Adams, J.Boyce-Kup, G.T.Edkins, C.R.Morling } \\
\text { W.E.Southcott,F.Sommer, H.D.Summers, J.Stewart }\end{array}$ \\
\hline 1908 & W.A.Morling & W.E.Southcott & $\begin{array}{l}\text { E.G.Adams, G.T.Edkins, C.R.Morling, G.W.Sheppard, F.Sommer } \\
\text { H.D.Summers, James Stewart, Ross Thomson }\end{array}$ \\
\hline 1909 & W.A.Morling & W.E.Southcott & $\begin{array}{l}\text { E.G.Adams, J.R.Brazier, W.M.howell, C.R.Morling } \\
\text { G.W.Sheppard, F.Sommer, Ross Thomson }\end{array}$ \\
\hline 1910 & W.A.Morling & W.E.Southcott & $\begin{array}{l}\text { A.S.Annand,W.A.Argent, Dr. R.Coltman, W.M.howell, K.F.Melchers } \\
\text { Major Nathan, J.Travers Smith, P.S.Thorton, Jas. Watts, C.M.G. }\end{array}$ \\
\hline 1911 & W.A.Morling & W.E.Southcott & $\begin{array}{l}\text { A.S.Annand, W.A.Argent, R.H.Chandless, W.M. Howell } \\
\text { K.F.Melchers, Major Nathan, R.E. J.Travers Smith }\end{array}$ \\
\hline 1912 & C.R.Morling & P.S.Thornton & $\begin{array}{l}\text { A.S.Annand, W.A.Argent, R.H.Chandless, K.H.Chun } \\
\text { W.M.Howell, K.F.Melchers, W.I.Pottinger }\end{array}$ \\
\hline 1913 & C.R.Morling & P.S.Thornton & $\begin{array}{l}\text { A.S.Annand, W.A.Argent, R.H.Chandless, IK.H.Chun } \\
\text { W.M.Howell, K.F.Melchers, W.I.Pottinger }\end{array}$ \\
\hline 1914 & C.R.Morling & P.S.Thornton & $\begin{array}{l}\text { A.S.Annand, W.A.Argent, R.H.Chandless, K.H.Chun } \\
\text { W.M.Howell, K.F.Melchers, W.i.Pottinger }\end{array}$ \\
\hline 1915 & $\begin{array}{l}\text { G.W.Sheppard } \\
\text { C.R.Morling }\end{array}$ & P.S.Thornton & $\begin{array}{l}\text { W.A.Argent, K.H.Chun, I.F.Drysdale, R.M.Gatliff, W.M.Howell } \\
\text { D.B.Nye, W.I.Pottinger }\end{array}$ \\
\hline 1916 & G.W.Sheppard & P.S.Thornton & $\begin{array}{l}\text { W.A.Argent, IK.H.Chun, I.F.Drysdale, R.M.Gatliff } \\
\text { W.M.Howell, D.B.Nye, W.I.Pottinger }\end{array}$ \\
\hline 1917 & $\begin{array}{l}\text { G.W.Sheppard } \\
\text { E.W.Carter }\end{array}$ & $\begin{array}{l}\text { P.S.Thornton } \\
\text { W.M.H } \\
\text { W.Mowell }\end{array}$ & $\begin{array}{l}\text { H.Chun, I.F.Drysdale, R.M.Gatliff, W.M.Howell } \\
\text { S.Knowls, D.B.Nye, W.I.Pottinger }\end{array}$ \\
\hline 1918 & E.W.Carter & \begin{tabular}{l|l}
$\begin{array}{l}\text { W.M.Howell } \\
\text { F.R.Scott }\end{array}$ & K.H \\
for
\end{tabular} & $\begin{array}{l}\text { H.Chun, R.M.Gatliff, R.W.Hamlet, G.S.Knowles and D.P.Ricketts } \\
\text { a portion of the year, N.L.eslie and Major W.S.Nathan,C.M.G.,R.E. }\end{array}$ \\
\hline
\end{tabular}

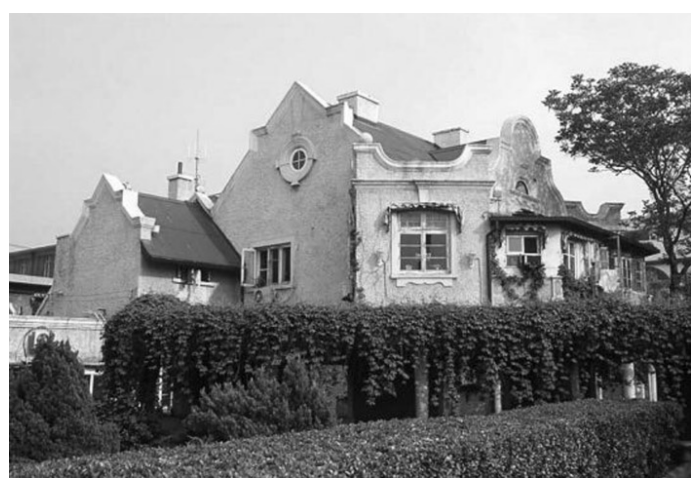

Photo 3 Former Residence of Davinci (build in1905)

photo 2, was two story building with the third level as antic with window all around which gave the room perfect lighting, that represents one of the characters of modern buildings.

4. The Middle stage of Tianjin's British Concession

4.1. The management system during Middle stage of British Concession

The previous chapter explained the management system. The management in the extended area was the same as the original British concession. In 1899 a Municipal Council was formed in the extended area. Many of the land owners of the extended area were foreigners, so the Municipal Council in the new area include the Councillors in the Original Concession. The chairman of the Municipal Council was the chairman of the Municipal Council in the original area. Between 1898 to 1918 all Councillors were foreigners and in 1899 to 1918 were two Chinese became Councillor (Table2). Tsai Shou Chi was one of the first group of Chinese students sent to study in American in 1872. He later became Customs Taotai in Tientsin as well as head of the Foreign Affairs Bureau, Chihli, under Yuan Shih-k'ai, and Principal of Peiyang university in Tientsin*16). And K.H.Chun was once Councillor, he

proposed to set up a Chinese school (Yaohua High School) in 1927.

\section{2. The development during Middle stage of British Concession}

From the annual of 1916,1917 and 1918 we can see the spread of constructions as indicated in Fig.5. within the Original British Concession were many foreign business facilities, Chinese constructions were not found, while in the extended area Chinese shops and residential houses were seen. The business extensions were mainly in the southern part where it belonged to America at the start. We can see that Americans was more passive in managing the concession and the majority of foreign constructions were in British concession while Chinese constructions were mainly built in the extended areas.

\section{3. The architectural style during Middle stage of British Concession}

The building of this time was still Western-style. 


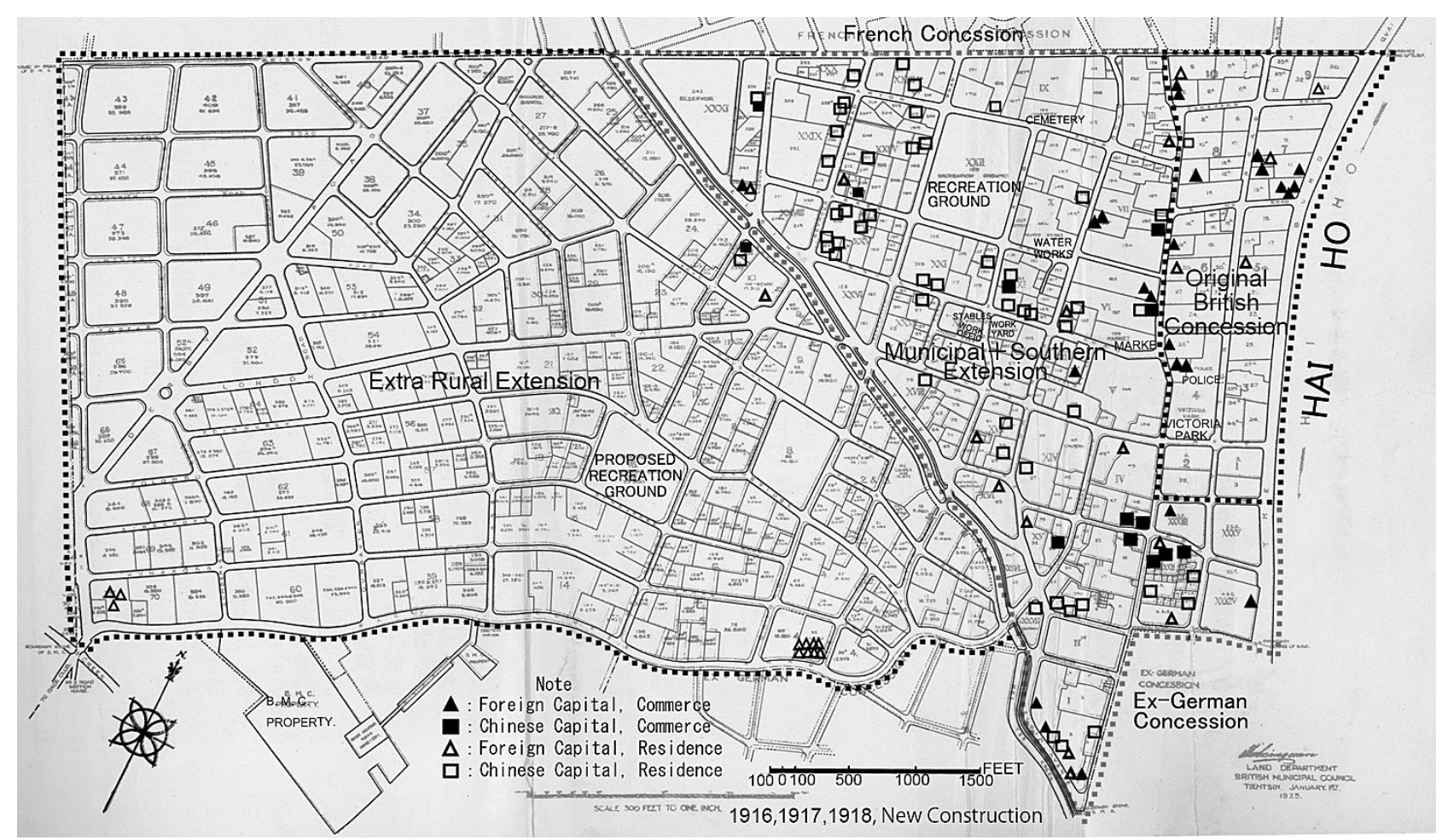

Fig.5 New Construction $(1916,1917,1918)$

There is an example (Photo 3). This house was built in 1905, the tow-storied brick-wood structure building*17) covers an area of about 1,800 square meters and a floor area of about 600 square meters, with red-tiled sloping roofs and cement plastering napping walls*18). The building showing a typical architectural style of Spanish folk residence.

5. The Late stage of Tianjin's British Concession

Table3 The member of Council Councillors during the last stage (from REPORTS OF THE BRITISH MUNICIPAL COUNCILS, 1938, AND MINUTES OF THE ANNUAL GENERAL MEETINGS 1939)

\begin{tabular}{|c|c|c|c|c|}
\hline Year & Chairman & Vice-Chairman & Hon.Treasurer & Councillors \\
\hline 1919 & E.W.Carter & F.R.Scott & R.G.Buchan & K.H.Chun, W.M.Howell, N.Leslie, F.W.Maze, Major W.S.Nathan, C.M.G.,R.E. and Dr.D.B.Nye. \\
\hline 1920 & E.W.Carter & W.M.Howell & R.G.Buchan & K.H.Chun, F.W.Maze, D.B.Nye, E.C.Peters, W.J.Warmsley and P.C.Young, C.B.E \\
\hline 1921 & $\begin{array}{l}\text { Major W.S. } \\
\text { Nathan, C.M.G., } \\
\text { P.C.Young, C.B. }\end{array}$ & \begin{tabular}{l|l||} 
& W.M.Howell \\
B.E.E. & \\
\end{tabular} & F.A.Fairchild & $\begin{array}{l}\text { M.Boniface, K.H.Chun, A.C.Cornish, F.A.Kennedy, W.W.G.Ross, R.H.R.Wade, } \\
\text { and for a portion of the year, E.C.Peter. }\end{array}$ \\
\hline 1922 & $\begin{array}{l}\text { P.C.Young, } \\
\text { C.B.E. }\end{array}$ & W.M.Howell & F.A.Fairchild & $\begin{array}{l}\text { A.C.Cornish, E.C.Peters, A.E.Tipper, R.H.R.Wade, and for a portion } \\
\text { and H.A.Lucker. }\end{array}$ \\
\hline 1923 & $\begin{array}{l}\text { P.C.Young, } \\
\text { C.B.E. }\end{array}$ & W.M.Howell & F.A.Fairchild & $\begin{array}{l}\text { E.W.Carter, K.H.Chun, H.A.Lucker, E.C.Peters, A.E.Tipper, R.H.R.Wade, and for a portion } \\
\text { of the year, W.E.Leckie. }\end{array}$ \\
\hline 1924 & $\begin{array}{l}\text { P.C.Young, C.B. } \\
\text { W.M.Howell }\end{array}$ & \multicolumn{2}{|c|}{ E.W.Carter } & $\begin{array}{l}\text { K.H.Chun, H.F.Dyott, H.A.Lucker, E.C.Peters, A.E.Tipper, James Turner, and for a portion } \\
\text { of the year, H.Bailey, R.G.Buchan and E.J.Nathan. }\end{array}$ \\
\hline 1925 & E.C.Peters & \multicolumn{2}{|c|}{ E.W.Carter } & $\begin{array}{l}\text { R.G.Buchan, K.H.Chun, W.M. Howell, H.A.Lucker. E.J.Nathan, Howard Payne and } \\
\text { James Turner and for a portion of the year A.E.Tipper and P.C.young, C.B.E. }\end{array}$ \\
\hline 1926 & $\begin{array}{l}\text { P.C.Young, } \\
\text { C.B.E. }\end{array}$ & \multicolumn{2}{|c|}{ W.J.Warmsley } & $\begin{array}{l}\text { G.H.Charleton, K.H.Chun, J.S. Chwang, H.A.Lucker, Howard Payne, E.C.Peters and } \\
\text { James Turner, and tor a portion of the year, R.T. McDonnell and R.H.Rowlatt. }\end{array}$ \\
\hline 1927 & $\begin{array}{l}\text { P.C.Young, } \\
\text { C.B.E. }\end{array}$ & \multicolumn{2}{|c|}{ E.C.Peters } & $\begin{array}{l}\text { K.H.Chun, S.M.Chung, J.S.Chwang, R.T.McDonnell, Howard Payne, James Turner and } \\
\text { W.J.Warmsley and for a portion of the year A.E.Tipper. }\end{array}$ \\
\hline 1928 & $\begin{array}{l}\text { P.C.Young, } \\
\text { C.B.E. }\end{array}$ & \multicolumn{2}{|c|}{ E.C.Peters } & $\begin{array}{l}\text { K.H.Chun, S.M.Chung, } \boldsymbol{D} \text {.S.Chwang, R.T.McDonnell, Howard Payne, A.E.Tipper and } \\
\text { W.J.Warmsiey, and tor a portion of the year C.D.Dixon. Z.S.Bien and A.Brearley. }\end{array}$ \\
\hline 1929 & $\begin{array}{l}\text { P.C.Young, } \\
\text { C.B.E. }\end{array}$ & \multicolumn{2}{|c|}{ E.C.Peters } & $\begin{array}{l}\text { Z.S.Bien, A.Brearley, H.K.Chang, K.H.Chun, S.M.Chung, J.S.Chwang, Howard Payne, and } \\
\text { A.E.Tipper and for a portion of the year T.S.Young and J.C. Taylor. }\end{array}$ \\
\hline 1930 & P.C.Young,C.B.E & \multicolumn{2}{|c|}{ J.S.Chwang } & Z.S.Bien, S.M.Chung, K.C.Hu, L.K.Liang, Howard Payne, E.C.Peters, J.C.Taylor and A.E.Tipper. \\
\hline 1931 & A.E.Tipper & & $\begin{array}{l}\text { A. Brearley, Chunta T.L. Chao, C.Cheng, Cheng Pin-zen, Howard Pavne, E.C.Peters, } \\
\text { Sun Feng-tsao and J.C.Taylor, and for a portion of the year C.K.Wang and K.Y.Pao. }\end{array}$ \\
\hline 1932 & A.E.Tipper & \multicolumn{2}{|c|}{ J.S.Chwang } & $\begin{array}{l}\text { A. Brearley, Chunta T.L. Chao, C.Cheng, K.Y.Pao, Howard Payne, E.C.Peters, J.C.Taylor, } \\
\text { and C.K.Wang, and for a portion of the year Li Ta, F.A.Perry and L.R.Rees. }\end{array}$ \\
\hline 1933 & $\begin{array}{l}\text { A.E.Tipper } \\
\text { E.C.Peters }\end{array}$ & \multicolumn{2}{|c|}{ J.S.Chwang } & $\begin{array}{l}\text { Z.S.Bien, Chunta T.L. Chao,L.V.Lanq, Li Ta, R.D.Murray, E.C.Peters, L.R.Rees and } \\
\text { and for a portion of the year Howard Payne. }\end{array}$ \\
\hline 1934 & E.C.Peters & \multicolumn{2}{|c|}{ J.S.Chwang } & $\begin{array}{l}\text { Z.S.Bien, Chunta T.L. Chao, L.V.Lang, Li Ta, H.H.Reed, L.R.Rees, James Turner } \\
\text { and C.K.Wang, and for a portion of the year W.F.Ridler. }\end{array}$ \\
\hline 1935 & E.C.Peters & \multicolumn{2}{|c|}{ J.S.Chwang } & $\begin{array}{l}\text { Z.S. Bien. Chunta T.L. Chao, Li Ta, C.E.Peacock, H.H.Reed, R.K.Rodger, James Turner } \\
\text { and C.K.Wang, and for a portion of the year D.O.Russell. }\end{array}$ \\
\hline 1936 & A.E.Tipper & \multicolumn{2}{|c|}{ J.S.Chwang } & $\begin{array}{l}\text { Chunta T.L. Chao, T.F.Hwang, Li Ta, E.C.Peters, H.H.Reed, R.K.Rodger, D.O.Russell, } \\
\text { and C.K.Wang, and for a portion of the year|Mr.C.H.Pian and Mr.C.D.Dixon. }\end{array}$ \\
\hline \begin{tabular}{|l|}
1937 \\
\end{tabular} & A.E.Tipper & \multicolumn{2}{|c|}{ J.S.Chwang } & $\begin{array}{l}\text { A.Burgess, Chunta T.L. Chao, C.D.Dixon. P.Y.Hsu, T.F.Hwang, R.K.Rodger, D.O.Russell, } \\
\text { and C.K.Wang. }\end{array}$ \\
\hline 1938 & $\begin{array}{l}\text { A.E.Tipper, } \\
\text { C.B.E }\end{array}$ & \multicolumn{2}{|c|}{ J.S.Chwang } & $\begin{array}{l}\text { A.Burgess, Chunta T.L. Chao, C.D.Dixon, P.Y.Hsu, T.F.Hwang, R.K.Rodger, D.O.Russell, } \\
\text { and C.K.Wang: and for a portion of the year.Mr.F.P.Ling, Mr.Keats S. Chu, } \\
\text { Mr.T.H.R.Candlin and Mr.J.A.Andrew }\end{array}$ \\
\hline
\end{tabular}


5. 1. The management system during Late stage of British Concession

Up to 1918 there was not formalized management in the extended area. According to the report on "Peking and Tientsin Times", an movement started in 1915 requisitions all the British concessions to merge. In oct.1917 a group of 180 people signed a petition which was sent to British government requesting that. After receiving the request, the British government order the consulate in Tianjin to hold a meeting to make a draft of merging. The "Municipal Bye-laws" drafted and announced in 1918. It was in action from 1 Jan. 1919. Thereafter based on "Municipal Bye-laws 1919" it started a new page in history.

In "Municipal Bye-laws" before 1918 explained the condition and privilege of voting. The number of votes was based on how much tax and rent you pay.

1899 the Municipal Council only consisted 5 people without the requirement of nationality. Before 1918 the Municipal Bye-laws required between 9 to 5 people and they must be British. However, in 1928 the requirement changed to between 10 to 5 and so long as 5 British nationals in was accepted. The rule set out in 1918 that non English speakers were not accepted was abolished. The rest of the regulation and function remained the same.

After 1928 Chinese members could reach 50\%. From only one Chinese at the Municipal Council in 1925 to 3 to 4 in 1930 and the assistant chairman of the Municipal Council was Chinese (Table3). The social statistics of Chinese has changed.

It should be noted that from 1930 to 1938, he was a Chinese named J.S. Chwang (莊 樂峰) who served vice-chairman. He was one of the founder of Yaohua high school (Photo.4 ${ }^{* 19}$ ) Fig.6) and was a man who held many other important positions ${ }^{* 20}$. In addition, several Chinese Councilors were confirmed. For example, Chunta T.L. Chao (趙天麟) was a Councilor in 1938, he was the principal of Yaohua High School*21).

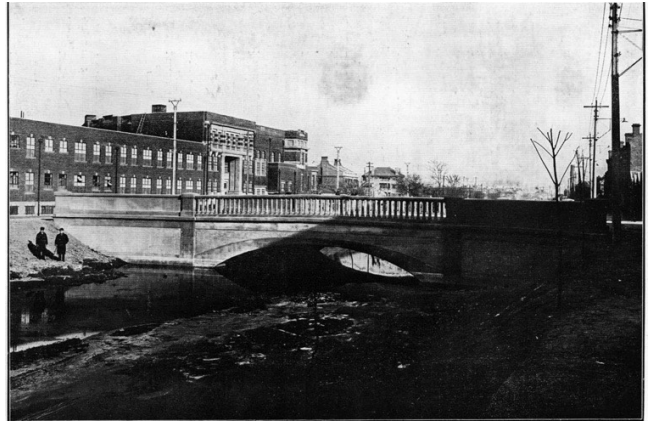

Photo 4 Yaohua high school in 1934

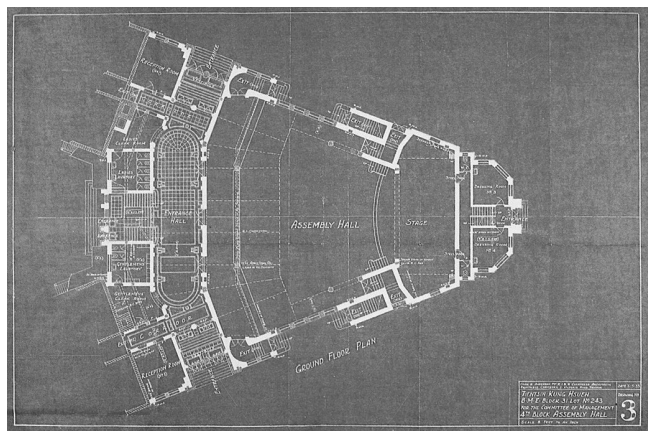

Fig.6 Yaohua high school Assembly Hall

\section{2. The development during Late stage of British Concession}

From the statistics in the annual report from BRITISH MUNICIPAL COUNCIL in 1919,1920,1921,1922, 1925 we can see the new infrastructure.

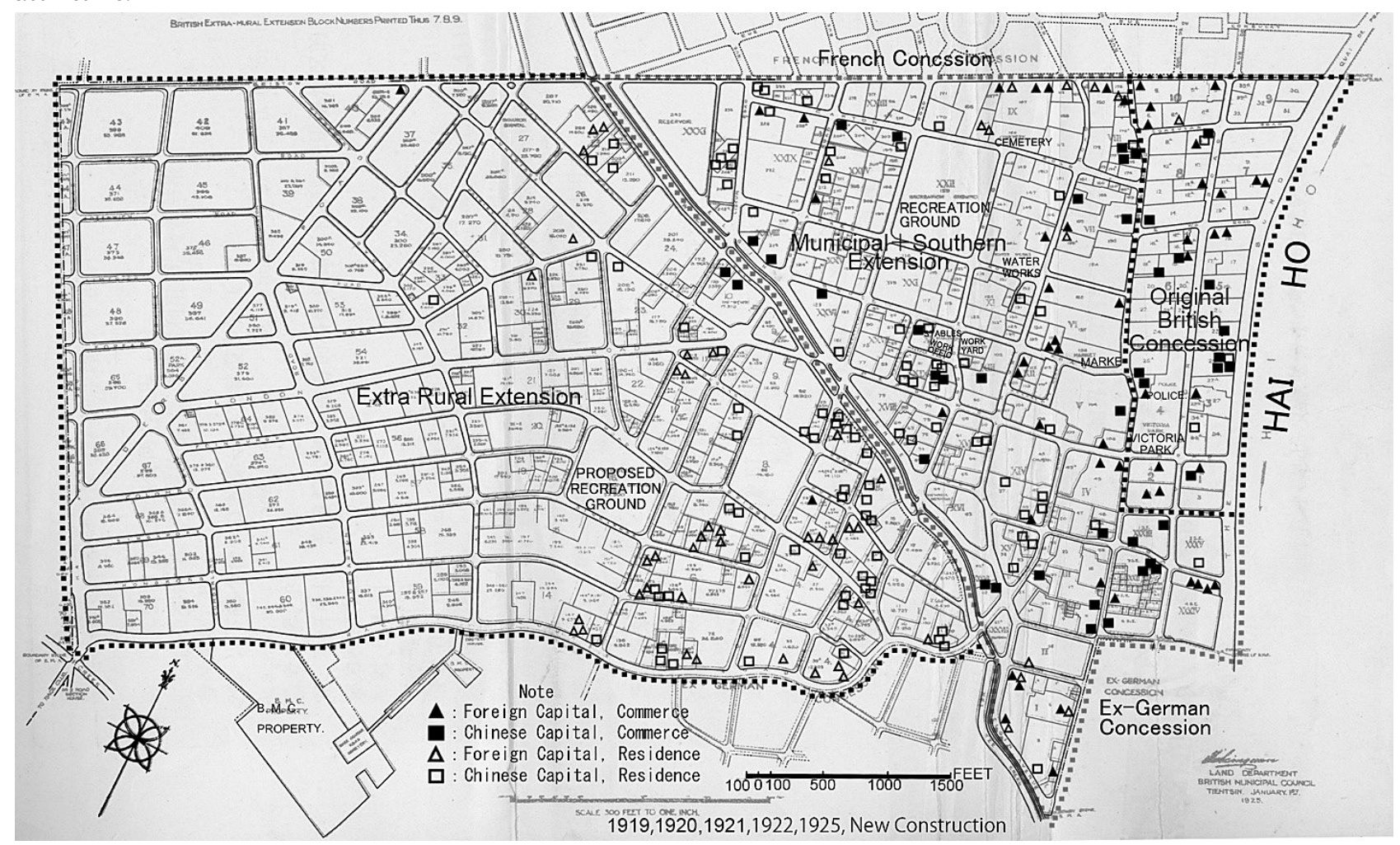

Fig.7 New Construction $(1919,1920,1921,1922,1925)$ 
First, along the development of the foreign business, Chinese business infrastructure, Chinese not only lived in British concession they also did business and their financial position has gone up. Of course, in the Original British concession there were limited residential places no matter it was foreign or Chinese.

Second, in the extended area, we can see both foreign and Chinese have built business facilities. As for residential buildings Chinese built more than foreigners.

Thirdly, in the extended area the work of filling the lower ground started in 1918, from the Municipal Extension towards the south. As soon as the ground was filled businesses and individuals took them and started to build residential housing and formed an appearance of residential area. As showed in Fig.7. The extended area did not have many business facilities. Residential houses were seen everywhere. The styles of these houses were Chinese which very different foreign styles were.

\subsection{The architectural style during Late stage of British Concession}

A change came to be seen in architecture style in the late stage. Because many upper classes Chinese people built houses in the British concession, Compromise between Chinese and European styles houses appeared. There are some examples.

Classiting as the heritage site under city protection and special protection historic architecture in Tianjin, the Former Residence of Prince Qing was built in 1922 by Zhang Lande (called Xiaodezhang (小德張) more popular), a eunuch of the Qing Dynasty. And then in1926, the Prince Qing of the Dynasty, Zai Zhen, Purchased it as his dwelling. Therefore, the building has been called. Palace of Price Qing. Zai Zhen (載振, 1876-1947), hereditary Prince Qing of Qing Dynasty, initially Zhen Guo General and later unsealed the rank of Beizi. In 1920, he was appointed special envoy minister to congratulate the crowning of the British King and Japan on invitations. He was appointed Minister of the Department of Commerce in 1906. In the next year, he was ordered to investigate and deal with events in three Northeast provinces. When he passed Tianjin, Duan Zhigui, the director of Patrolmen Station in southern section of Tianjin, bought an actress named Yang Cuixi and sent him as a concubine. Duan Zhigui was promoted the governor of Heilongjiang Province. After a short while, the issue was disclosed by the censor Zhao Qilin. The imperial court assigned an official to investigate and ended it up with nothing definite in the reason of no actual evidence. Thereafter, Zai Zhen resigned all positions. During his stay in Tianjin, he invested in come industrial projects including Quanyechang Mall, a department store established by Xinye Company which was owned by comprador Gao Xingqiao and Communication Hotel for his expenditures of living.

Covering an area of $4700 \mathrm{~m}^{2}$ and with a floor area of about $5000 \mathrm{~m}^{2}$, the architecture was laid out in an enclosing form with a courtyard inside. Along with the basement, this brick-wood structure is two-storied and has got two ranges of the open colonnades respectively for both layers. The design is simple but tasteful. The shared lobby in the building is giant and elegant, suitable for the western life-style at time. The traditional Chinese glazed blusters take the granitic stucco walls as their background and the classical Chinese flower-bird figures made of the Belgian glass seem lifelike. The Chinese and western cultures have been mingled with other by the design (Photo 5).

The heritage listed Chen Guangyuan's (陳光遠) residence is now a Kindergarten. Borne in Wuqing, Tianjin, Chen Guangyuan held many titles in the army. After 1911 Revolution he became consultant officer in the office of the president, commander of the Rehe guarding camp and the garrisoning commissioner of Chifeng. When Yuan Shikai (袁世凱) established military demonstration regiment in 1914 , he was appointed deputy regimental commander and the superintendent of troop training division in New Army. In 1917, he was appointed head of Beijing-Tianjin Garrison, commander of Suiyuan, provincial military governor of Jiangxi Province, named as "Three Governors Along Yangtze River" along with $\mathrm{Li}$ Chun, provincial military governor of Jiangsu Province and Wang
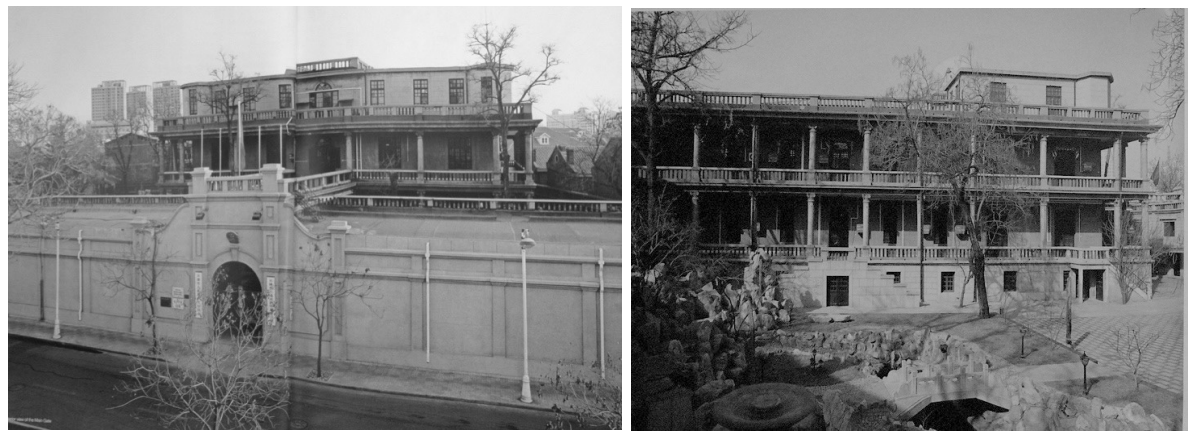

Photo 5 Former Residence of Prince Qing

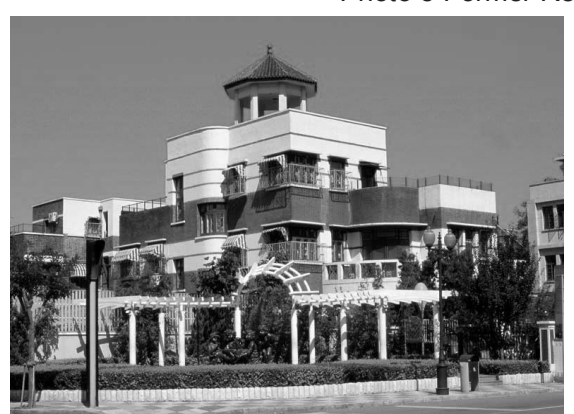

Photo 6 Former Residence of Chen Guangyuan

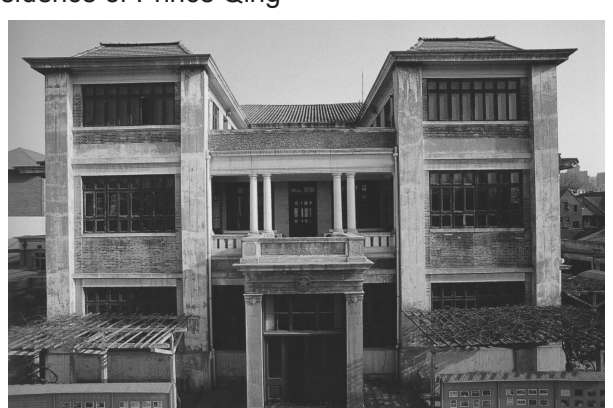

Photo 7 Former Residence of Cai Chengxun 
Zhanyuan, provincial military governor of Hubei Province. Defeated by the Northern Army in 1922, Chen Guangyuan left his post and moved to Tianjin. He purchased lots of real estates and invested in business successfully.

Built in 1924, the three-storied brick-wood structure building covers an area of about $1000 \mathrm{~m}^{2} \mathrm{~s}$ and a floor area of about $1200 \mathrm{~m}^{2}$, with irregular plan layout and elevations at different levels. The exterior wall consists of light plastered bricks walls and dark glazed quarry tiles, showing conciseness and good taste in a modern architecture style. There is a terrace on the roof, with Chinese style glaze tiled octagonal bower, providing the whole building a feature of Chinese and Western styles ${ }^{* 22}$ (photo 6).

Born in Tianjin, Cai Chengxun (蔡成勛, 1871-1946) graduated from Beiyang Military School and was appointed consultant of Troop Training Division near Beijing and the commander of the 41 ${ }^{\text {st }}$ Mixed Brigade in Zhejiang Province. After the Revolution of 1911, he was named aide-de-camp of the president, commander of the first Division, commander of the seventh Army Corps in South Expedition, provincial governor of Chahar, Chief of Army in 1921 and provincial military governor of Jiangxi Province in 1922. He returned to Tianjin and made his home there in 1924, investing in businesses ${ }^{* 23}$.

The three-storied brick-wood structure building was constructed in 1935 (Photo 6). The architectural composition is in symmetry, bays being large. The advanced wood floor, clapboards, staircases and ground openwork partition are luxury and delicate, being rare collections of engravings. The exterior wall is built with black bricks, with simple architectural contour and imposing manner, presenting an eclectic architectural style ${ }^{* 24}$ (Photo 7).

As can be seen from the above, the construction by the Chinese in the British concession were mainly housing. Also, it was the people of the upper class in China who were able to construct the housing.

\section{Conclusion}

In the Early stage of the British concession, it did not assimilate into the local community, and there was no objection to "countries within a country". However, from the middle stage to the latter stage, the British concession began to integrate into the local community and the integration went well. The concession space was created by colonial policy, so to speak, it was totally alien to locals in the early stage. However, a change gradually happened from within the concession as time passed. The concession weaved into local culture and a totally new space was created. As a result, the design of urban infrastructure such as road network plan was European style, whereas the buildings built on it were presenting an eclectic architectural style. This created a unique landscape not only in traditional Chinese cities but also in Europe.

The evolution of cities has many points in common with the evolution of biological evolution. Concessions planned and developed by foreigners were exotic species. Such exotic species change the surrounding environment over time. However, at the same time, depending on the surrounding environment, the organism itself will also change. As a result, a completely new creature was born.

Such a phenomenon was seen in other concessions. For example, the Continental Bank was opened in 1919 in Tianjin and located at French Concession. It was one of the "four northern banks" and invested by Feng Guozhang(馮國璋), the President of the Republic of China, Li Chun(李純), the Jiangsu Military Governor and Qi Yaolin(齐耀琳), the then Governor of Jiangsu Province. The core business of the bank was in trust, stocks and securities and it had invested in warehousing and broke up British Pinghe Company's monopoly of the warehousing industry in Tianjin. The Continental Bank was closed sown in 1953. The office building of Continental Bank was built in 1921. It covers an area of some $2,000 \mathrm{~m}^{2}$ and its floor area was about $4,900 \mathrm{~m}^{2}$. This three-storied brick-concrete building with a basement was designed by Jitai Engineering (Kwan, Chu and Yang Architects) Company and belongs to eclectic architecture. The exterior furred wall ${ }^{* 25}$ ) was decorated with Ionic pilaster block ${ }^{* 26)}$ and a tower was built on the roof, the rooms are well laid out and beautifully decorated, bearing the characteristics of eclectic architecture ${ }^{* 27}$. It seems that the same phenomenon also occurred in other concessions.

Let's compare it with other countries in Asia. In Japan, for example, foreign settlements were established from around 1858. Immediately after that, the Japanese carpenter imitated the western style building of the settlement and built "mimicked Western-style architectures（擬洋風建築）". After that, like Tatsuno Kingo（辰野金吾）, Japanese architect who learned full-fledged modern architecture from "Foreign government advisors in Meiji Japan（お雇い外国人）" became active. The architectures built in Tianjin's British Concession has similarities to "mimicked Western-style architectures（擬洋風建築）". However, those architectures were not build in the early stage of British Concession, but after the modernization has progressed. Also, the presence of foreign engineers employed in China was known. However, the Chinese architects taught to them were not known. I will discuss the topic in my future article.

\section{Acknow ledgement}

This paper was revised and added extensively based on the doctoral thesis submitted to University of Tsukuba in 2015. This research received advice from many teachers. I would like to thank Professor Aoki Nobuo（青木信夫），Professor Xu Subin（徐苏斌）， Mr. Luo Shuwei (罗澍伟) , Mr. Wan Xinping (万新平) , Mr. Zhang Limin（张利民） for useful advice. 
1) O.D.Rasmussen: Tientsin: An Illustrated Outline History, The Tientsin Press, Ltd. 1925

2) O.D.Rasmussen: The Growth of Tientsin, The Tientsin Press, Ltd. 1924

3) REPORTS OF THE BRITISH MUNICIPAL COUNCILS, AND MINUTES OF THE ANNUAL GENERAL MEETINGS, from 1906 to 1926 ware English text, which were stored in Tianjin Archive Museum. 1907, 08, 09, 11, 13, 15, 23, 24, 26 years are missing. After 1927, except for 1928, the reports were translated into Chinese and published as a book in 2012 as Tianjin British Municipal Councils Historical Election Chapters. All of this article used the English text which is stored in Tianjin Archive Museum.

4) Wu YanLong: Historic Architecture in Tianjin, Residence Volume 1、2, Tianjin University Press, 2010

5) Wu YanLong: Historic Architecture in Tianjin, Public Building Volume 1、2, Tianjin University Press, 2010

Notes

* 1) Hong Zhang: Settlement: countries within a country, SHANGHAI WAVE, 2007 pp.62-63

*2) Tianjin Local Records Compilation Committee: Tianjin Historical Collection, about Concessions, Tianjin Academy of Social Sciences, 1996 , p.71

*3) ibid.

* 4) Robert Home: Of Planting and Planning: The making of British colonial cities, Taylor \& Francis,1997

* 5) Wang Shao: Yangtze Riverside's "Country of the Country": Zhenjiang British Concession, Teaching and Training in Zhenjiang Teachers College:

Language and Literature Edition, 1984, pp.108-112 王骧：扬子江滨的“国中之国”-镇江英租界始末,教学与进修, 1984, pp.108-112

*6) ONDA Shigenao: A STUDY ON THE FORMATION PROCESS OF HABER SPACE IN AMOY, CHINA, J. Archit. plan., AIJ, No.527, 2003, pp.201-208

* 7) WANG Yiwu, KAMINO Keijin, FUNAHASHI Kunio, OKU Toshinobu, KOURA Hisako, KITA Michihiro: A Study on the Land-Use and Building Function in Tianjin Concession, Papers on city planning 30, 1995, pp.445-450

* 8) Yichen Liu, Masaki Fujikawa: The Development Intent and Details of the British Extra Rural Extension in Tianjin, China, J. Archit. Plann., No.704, 2014, pp.2191-2198

*9)Yichen Liu, Masaki Fujikawa: The Development Process of the Original British Concession in Tianjin, China, J. Archit. Plann., No.712, 2015, pp.1285-1294

*10) CHEN Guodong, AOKI Nobuo, XU Subin, DANA Arnoid: Expansion of British Concessions and Contested Collages of Nine Concessions: Town Planning of the British Concession in Tianjin, 1860-1943, Urban planning journal, 2017, 104-112 陈国栋,青木信夫,徐苏斌,达纳·阿诺德:英租界殖民路径与九国租界 竞争性拼贴——以天津英租界(1860-1943)规划为重点, 城市规划学刊, 2017, 104-112

* 11) Tianjin Local Records Compilation Committee: Tianjin Historical Collection, about Concessions, Tianjin Academy of Social Sciences, 1996, pp.81-82

$* 12$ ) ibid

* 13) After Lee Hongzhang passed the Imperial examination, he learned from Zeng Guofan (曾国藩), organized the Huai Army, and crushed Taiping Rebellion as Jiangsu Grand coordinator and provincial governor. After serving as Viceroy of Huguang and Liangguang, In 1870, he became Viceroy of Zhili, and was in charge of Qing Dynasty's diplomacy. In Japan, he is known as the representative of the Chinese side signed the Shimonoseki treaty after the Sino-Japanese War. In addition, Li Hongzhang promoted the Self-Strengthening Movement to adopt Western culture for the modernization of China. Tianjin was said to have been the very center. Tianjin Regional History Research Association: Tianjin history - Reproducing Urban topology, Tohoshoten, 1999, pp.16-17

* 14) The Directory \& Chronicle for China, Japan, Corea, Indo-China, Straits Settlements, Malay States, Sian, Netherlands India, Borneo, the Philippines, \&c: With which are Incorporated "The China Directory" and "The Hong Kong List for the Far East" ..., Hongkong daily Press office, 1877, p.326

* 15) The reasons for selecting cases are as follows. People (companies) who build or purchase the building is notorious. The size of the building is large and it is gorgeous. As a result, the impact on the current urban landscape of Tianjin is also great

* 16) George Ernest Morrison: The Correspondence of G. E. Morrison 1895-12, Cambridge University Press, 1976 , p.708

*17) brick-wood structure building については、耐力壁と柱等、垂直方向に負荷を担う構造はレンガで造り、スラブ等は木造で造られた建物。

*18) cement plastering napping walls については、セメントとモルタルで凸凹のある壁面に仕上げていることを指す。

* 19) From REPORTS OF THE BRITISH MUNICIPAL COUNCILS, 1934, AND MINUTES OF THE ANNUAL GENERAL MEETINGS, 1935

* 20) Tianjin Local Records Compilation Committee; Tianjin Historical Collection, about Concessions, Tianjin Academy of Social Sciences, 1996 , p.356

* 21) Chunta (君達) was His Courtesy name. From China Archives News 2010.9.16.

*22) Wu YanLong: Residence Volume 2, 2010, pp.36-39

*23) ibid, pp32-33

$* 24)$ ibid

*25) furred wall については、壁の表面を毛が立っているように粗く仕上げた状態を指す。

*26) Ionic pilaster block については、イオニア式の柱形ブロックのことを指す。

*27) Wu YanLong: Public Building Volume 2, 2010, pp.54-55

\section{和文要約}

これまで、租界や居留地などの植民都市は、「植えつけられた都 市」あるいは「国の中の国」との評価をされてきた。本研究では その評価を批判的に捉え、現地の人、現地の地域社会との関わり方 に着目し、時間が経つにつれて、植民都市が現地の地域社会に同化 していく現象を解明した。

本研究は、中国天津の英租界を取り上げ、それが拡張された時期 に合わせて三つに時期を区分し、すなわち 1860 年〜1897 年を租 界時代前期、1897 年 1918 年を租界時代中期、1918 年～1943 年 租界時代後期とした。時代が移行するにつれ、租界の運営、租界内
における開発、建設された建築の様式について、中国人がら゙のよう に関わり、どのような都市空間が生まれたのかを明らかにした。 結果として、租界時代前期、中期においては、外国人によって外 国人のための空間である性格は強いが、租界時代後期になると、中 国人が租界の運営、開発に強く関わるようになり、段階的現地の地 域社会に同化し、定着していった。また、伝統的な中国的要素をも つ折表様式の建築も造られた。したがって、租界は伝統的な中国の 都市とは異なる空間であることは言うまでもなく、欧米の都市とも 異なる新しい都市空間であると評価できる。 